\title{
Algoriphagus lutimaris sp. nov., isolated from a tidal flat sediment
}

\author{
Sooyeon Park, So-Jung Kang, Ki-Hoon Oh, Tae-Kwang Oh \\ and Jung-Hoon Yoon
}

Correspondence
Jung-Hoon Yoon
jhyoon@kribb.re.kr
Korea Research Institute of Bioscience and Biotechnology (KRIBB), PO Box 115, Yusong, Taejon, Republic of Korea
The genus Algoriphagus was first proposed by Bowman et al. (2003) and belongs phylogenetically to the phylum Bacteroidetes (Nedashkovskaya et al., 2007). Since the proposal of the genus, further descriptions of novel species and reclassifications of members of the genera Hongiella and Chimaereicella have increased the number of species belonging to the genus Algoriphagus considerably (Nedashkovskaya et al., 2004, 2007; Van Trappen et al., 2004; Yoon et al., 2005a, b, 2006; Copa-Patiño et al., 2008; Liu et al., 2009). At the time of writing, the genus Algoriphagus comprised 17 species with validly published names and members have been isolated from sea ice, seawater, algae, marine sediments, soil and fresh water (Nedashkovskaya et al., 2007; Copa-Patiño et al., 2008; Liu et al., 2009). In this study, we report on the taxonomic characterization of an Algoriphagus-like bacterial strain, S1 $-3^{\mathrm{T}}$, which was isolated from a tidal flat sediment on the west coast of Korea.

Strain $\mathrm{S} 1-3^{\mathrm{T}}$ was isolated by means of the standard dilution-plating technique at $25{ }^{\circ} \mathrm{C}$ on marine agar 2216 (MA; Difco). Algoriphagus halophilus KCTC $12051^{\mathrm{T}}$, which was used as a reference strain for phenotypic characteriza-

The GenBank/EMBL/DDBJ accession number for the 16S rRNA gene sequence of strain $\mathrm{S} 1-3^{\top}$ is FJ669216.

Maximum-likelihood and maximum-parsimony trees based on 16S rRNA gene sequences are available as supplementary material with the online version of this paper. tion, fatty acid analysis and DNA-DNA hybridization, was obtained from the Korean Collection for Type Cultures. The morphological, physiological and biochemical characteristics of strain $\mathrm{S} 1-3^{\mathrm{T}}$ were investigated after cultivation on MA at $30{ }^{\circ} \mathrm{C}$. Cell morphology was examined by light microscopy (Nikon E600) and transmission electron microscopy. Flagellation was determined by using a Philips CM-20 transmission electron microscope with cells from exponentially growing cultures. For this purpose, the cells were negatively stained with $1 \%(\mathrm{w} / \mathrm{v})$ phosphotungstic acid and the grids were examined after being airdried. Gliding motility was investigated as described by Bowman (2000). The Gram reaction was determined by using the bioMérieux Gram-stain kit according to the manufacturer's instructions. Growth in the absence of $\mathrm{NaCl}$ and in the presence of $0.5,1.0,2.0$ and $3.0 \%(\mathrm{w} / \mathrm{v})$ $\mathrm{NaCl}$ was investigated with trypticase soy broth (Difco) that had been prepared according to the manufacturer's instructions except that $\mathrm{NaCl}$ was added to the desired final concentration and $0.45 \%(\mathrm{w} / \mathrm{v}) \mathrm{MgCl}_{2} \cdot 6 \mathrm{H}_{2} \mathrm{O}$ or $0.06 \%$ $(\mathrm{w} / \mathrm{v}) \mathrm{KCl}$ were used as supplements. Growth at 2.0-10.0\% $(\mathrm{w} / \mathrm{v}) \mathrm{NaCl}$ (in increments of $1.0 \%$ ) was investigated in marine broth 2216 (MB; Difco). Growth at 4, 10, 20, 25, $28,30,35,37,40$ and $45{ }^{\circ} \mathrm{C}$ was measured on MA. The $\mathrm{pH}$ range for growth was determined in $\mathrm{MB}$ that was adjusted to $\mathrm{pH} 4.5-9.5$ (in increments of $0.5 \mathrm{pH}$ units) by the addition of $\mathrm{HCl}$ or $\mathrm{Na}_{2} \mathrm{CO}_{3}$. Growth under anaerobic conditions was determined after incubation in a Forma 
anaerobic chamber on MA and on MA supplemented with potassium nitrate $(0.1 \%, \mathrm{w} / \mathrm{v})$, both of which had been prepared anaerobically in a nitrogen atmosphere. Catalase and oxidase activities were determined as described by Cowan \& Steel (1965). Hydrolysis of casein, starch, hypoxanthine, tyrosine and xanthine was tested on MA, using the substrate concentrations described by Cowan \& Steel (1965). Hydrolysis of aesculin, gelatin, Tweens 20, 40, 60 and 80 and urea and nitrate reduction were investigated as described by Lányí (1987) with the modification that artificial seawater was used for medium preparation. The artificial seawater contained $\left(1^{-1}\right.$ distilled water $)$ $23.6 \mathrm{~g} \mathrm{NaCl}, 0.64 \mathrm{~g} \mathrm{KCl}, 4.53 \mathrm{~g} \mathrm{MgCl}_{2} .6 \mathrm{H}_{2} \mathrm{O}, 5.94 \mathrm{~g}$ $\mathrm{MgSO}_{4} \cdot 7 \mathrm{H}_{2} \mathrm{O}$ and $1.3 \mathrm{~g} \mathrm{CaCl} \cdot 2 \mathrm{H}_{2} \mathrm{O}$ (Bruns et al., 2001). $\mathrm{H}_{2} \mathrm{~S}$ production was tested as described by Bruns et al. (2001). The presence of flexirubin-type pigments was investigated as described by Reichenbach (1992). For pigment absorption-spectrum analysis, strain $\mathrm{S} 1-3^{\mathrm{T}}$ was cultivated aerobically in the dark at $30{ }^{\circ} \mathrm{C}$ in $\mathrm{MB}$. The culture was centrifuged, washed twice using a MOPS buffer $\left(0.01 \mathrm{M} \quad \mathrm{MOPS} / \mathrm{NaOH}, \quad 0.1 \mathrm{M} \quad \mathrm{KCl}, 0.001 \mathrm{M} \mathrm{MgCl}_{2}\right.$, $\mathrm{pH}$ 7.5) and disrupted by sonication with a Branson Sonifier 450. After removal of cell debris by centrifugation, the absorption spectrum of the supernatant was examined on a Beckman Coulter DU800 spectrophotometer. Acid production from carbohydrates was determined as described by Leifson (1963). Utilization of substrates as sole carbon and energy sources was tested as described by Baumann \& Baumann (1981) using supplementation with $2 \%(\mathrm{v} / \mathrm{v})$ Hutner's mineral base (Cohen-Bazire et al., $1957)$ and $1 \%(\mathrm{v} / \mathrm{v})$ vitamin solution (Staley, 1968). Susceptibility to antibiotics was tested on MA plates using antibiotic discs containing the following ( $\mu \mathrm{g}$ unless otherwise stated): polymyxin B (100 U), streptomycin (50), penicillin G (20 U), chloramphenicol (100), ampicillin (10), cephalothin (30), gentamicin (30), novobiocin (5), tetracycline (30), kanamycin (30), lincomycin (15), oleandomycin (15), neomycin (30) and carbenicillin (100). Other physiological and biochemical tests were performed with the API 20E and API ZYM systems (bioMérieux).

Cell biomass of strain $\mathrm{S} 1-3^{\mathrm{T}}$ for DNA extraction and for isoprenoid quinone analysis was obtained from cultures grown for 3 days in $\mathrm{MB}$ at $30{ }^{\circ} \mathrm{C}$. Chromosomal DNA was isolated and purified according to the method described previously (Yoon et al., 1996), with the exception that RNase T1 was used in combination with RNase A to minimize contamination with RNA. The $16 \mathrm{~S}$ rRNA gene sequence was amplified by PCR using two universal primers as described previously (Yoon et al., 1998). Sequencing and phylogenetic analysis were performed as described previously (Yoon et al., 2003). The identification of phylogenetic neighbours was achieved using the EzTaxon server (http://www.eztaxon.org/; Chun et al., 2007). Isoprenoid quinones were extracted according to the method of Komagata \& Suzuki (1987) and analysed using reversed-phase HPLC and a YMC ODS-A $(250 \times 4.6 \mathrm{~mm})$ column. For fatty acid methyl ester analysis, cell mass of
Table 1. Differential phenotypic characteristics of Algoriphagus lutimaris sp. nov. $\mathrm{S} 1-3^{\top}$ and $A$. halophilus JC $2051^{\top}$

Strains: 1, A. lutimaris sp. nov. S1-3 ${ }^{\mathrm{T}} ; 2$, A. halophilus JC $2051^{\mathrm{T}}$ (unless indicated, data from Yi \& Chun, 2004; Nedashkovskaya et al., 2004). Both strains are Gram-negative and rod-shaped and positive for catalase, oxidase, hydrolysis of aesculin and gelatin, utilization of cellobiose, D-glucose, D-fructose, maltose, D-mannose, salicin, sucrose, trehalose and D-xylose, acid production from L-arabinose, Dglucose, lactose, maltose, D-mannose, raffinose and L-rhamnose, activity of alkaline phosphatase, esterase lipase (C8), leucine arylamidase, cystine arylamidase, trypsin, $\alpha$-chymotrypsin, acid phosphatase, naphthol-AS-BI-phosphohydrolase and $N$-acetyl- $\beta$-glucosaminidase and susceptibility to carbenicillin, chloramphenicol, lincomycin and oleandomycin. Both strains are negative for flagellation, gliding motility, production of flexirubin-type pigments, nitrate reduction, $\mathrm{H}_{2} \mathrm{~S}$ and indole production, arginine dihydrolase, hydrolysis of agar, cellulose, starch, urea, tyrosine and xylan (data for the latter two substrates obtained in this study for A. halophilus KCTC $12051^{\mathrm{T}}$ ), utilization of acetate, citrate, formate, L-glutamate, succinate, benzoate, L-malate and pyruvate, acid production from myoinositol, D-mannitol, D-ribose and D-sorbitol, activity of lipase (C14), $\alpha$-galactosidase, $\beta$-glucuronidase, $\alpha$-mannosidase and $\alpha$-fucosidase and susceptibility to ampicillin, penicillin G, cephalothin, gentamicin, kanamycin, neomycin, novobiocin, polymyxin B and streptomycin. + , Positive; w, weakly positive; - , negative.

\begin{tabular}{|c|c|c|}
\hline Characteristic & 1 & 2 \\
\hline $\begin{array}{l}\text { Wavelength of maximum absorption peak } \\
(\mathrm{nm})\end{array}$ & 467 & 475 \\
\hline $\mathrm{NaCl}$ requirement for growth & $-{ }^{*}$ & + \\
\hline Optimal growth temperature $\left({ }^{\circ} \mathrm{C}\right)$ & 30 & 35 \\
\hline \multicolumn{3}{|l|}{ Hydrolysis of: } \\
\hline Casein & + & - \\
\hline DNA & + & - \\
\hline \multicolumn{3}{|l|}{ Utilization of: $\dagger$} \\
\hline L-Arabinose & - & $\mathrm{W}$ \\
\hline D-Galactose & - & + \\
\hline \multicolumn{3}{|l|}{ Acid production from: $\dagger$} \\
\hline Cellobiose & - & + \\
\hline D-Fructose & - & + \\
\hline D-Galactose & + & - \\
\hline Melezitose & - & + \\
\hline Melibiose & - & + \\
\hline Sucrose & - & + \\
\hline Trehalose & + & - \\
\hline D-Xylose & - & + \\
\hline \multicolumn{3}{|l|}{ Enzyme activity (API ZYM) $\dagger$} \\
\hline Esterase (C4) & - & + \\
\hline Valine arylamidase & - & $\mathrm{W}$ \\
\hline$\beta$-Galactosidase & - & + \\
\hline$\alpha$-Glucosidase & - & + \\
\hline$\beta$-Glucosidase & - & + \\
\hline Susceptibility to tetracycline & - & + \\
\hline DNA G $+C$ content $(\mathrm{mol} \%)$ & 41.4 & 42 \\
\hline
\end{tabular}

${ }^{*}$ Growth in the absence of $\mathrm{NaCl}$ occurs when $\mathrm{Mg}^{2+}$ ions are added. $\dagger$ Data for A. halophilus KCTC $12051^{\mathrm{T}}$ from this study. 
strain S1-3 $3^{\mathrm{T}}$ and A. halophilus KCTC $12051^{\mathrm{T}}$ was harvested from MA plates after incubation for 3 days at $30{ }^{\circ} \mathrm{C}$. The fatty acid methyl esters were extracted and prepared according to the standard protocol of the MIDI/Hewlett Packard Microbial Identification System (Sasser, 1990). The DNA G + C content was determined by the method of Tamaoka \& Komagata (1984) with the modification that DNA was hydrolysed and the resultant nucleotides were analysed by reversed-phase HPLC. DNA-DNA hybridization was performed fluorometrically by the method of Ezaki et al. (1989) using photobiotin-labelled genomic DNA probes for cross-hybridization experiments in microdilution wells. Hybridization was performed with five replications for each sample. The highest and lowest values obtained in each sample were excluded and the means of the remaining three values were quoted as DNADNA relatedness values.

Morphological, cultural, physiological and biochemical characteristics of strain $\mathrm{S} 1-3^{\mathrm{T}}$ are given in the species description and in Table 1 . Sonicated cell extracts of strain S1- $3^{\mathrm{T}}$ showed an absorption peak maximum at $467 \mathrm{~nm}$, which indicates the presence of carotenoids. Flexirubintype pigments were not produced, as shown by the negative $\mathrm{KOH}$ test result. An almost-complete $16 \mathrm{~S}$ rRNA gene sequence of strain $\mathrm{S} 1-3^{\mathrm{T}}$, comprising $1475 \mathrm{nt}$ (approx. $96 \%$ of the Escherichia coli 16S rRNA sequence), was determined in this study. In the neighbour-joining phylogenetic tree based on 16S rRNA gene sequences, strain S1-3 $3^{\mathrm{T}}$ fell within the clade comprising Algoriphagus species and formed a coherent cluster with $A$. halophilus IMSNU $14013^{\mathrm{T}}$ with a bootstrap resampling value of $100 \%$ (Fig. 1). The close relationship between strain $\mathrm{S} 1-3^{\mathrm{T}}$ and $A$. halophilus IMSNU $14013^{\mathrm{T}}$ was also found in trees constructed using the maximum-likelihood and maximum-parsimony algorithms (Supplementary Fig. S1, available in IJSEM Online). The 16S rRNA gene sequence similarity between strain $\mathrm{S} 1-3^{\mathrm{T}}$ and A. halophilus IMSNU $14013^{\mathrm{T}}$ was $99.6 \%$. Strain $\mathrm{S} 1-3^{\mathrm{T}}$ exhibited $16 \mathrm{~S}$ rRNA gene sequence similarity of $94.0-97.1 \%$ to the type strains of the other Algoriphagus species and less than $92.5 \%$ to the type strains of the other species used in the phylogenetic analysis.

The predominant isoprenoid quinone detected in strain S1- $3^{\mathrm{T}}$ was menaquinone-7 (MK-7), which is the same as that found in other members of the genus Algoriphagus (Nedashkovskaya et al., 2004, 2007). The cellular fatty acid profiles of strain $\mathrm{S} 1-3^{\mathrm{T}}$ and A. halophilus KCTC $12051^{\mathrm{T}}$ obtained in this study are shown in Table 2. The major fatty acids ( $>10 \%$ of total fatty acids) in strain $\mathrm{S} 1-3^{\mathrm{T}}$ were $\mathrm{C}_{16: 1} \omega 7 c$ and/or iso- $\mathrm{C}_{15: 0} 2-\mathrm{OH}$ and iso- $\mathrm{C}_{15: 0}$. The fatty acid profiles were similar in the two strains, though there were differences in the proportions of some fatty acids. The DNA G $+C$ content of strain $\mathrm{S} 1-3^{\mathrm{T}}$ was $41.4 \mathrm{~mol} \%$. The chemotaxonomic analysis showed that strain $\mathrm{S} 1-3^{\mathrm{T}}$ shared properties found in Algoriphagus species and was in agreement with the finding from the phylogenetic analysis that strain $\mathrm{S} 1-3^{\mathrm{T}}$ may be a member of the genus Algoriphagus (Bowman et al., 2003; Nedashkovskaya et al., 2004, 2007).

The mean DNA-DNA relatedness value between strain S1-3 ${ }^{\mathrm{T}}$ and A. halophilus KCTC $12051^{\mathrm{T}}$ was $48 \%$, which indicates that the two strains are members of different genomic species (Wayne et al., 1987). Strain $\mathrm{S} 1-3^{\mathrm{T}}$ was distinguishable from A. halophilus KCTC $12051^{\mathrm{T}}$ by differences in several phenotypic characteristics, most of which were determined using the same methods in this study (Table 1). The phylogenetic distinctiveness of strain $S 1-3^{\mathrm{T}}$, together with the genetic distinctiveness and differential phenotypic properties, are sufficient to show that this strain is separate from other Algoriphagus species

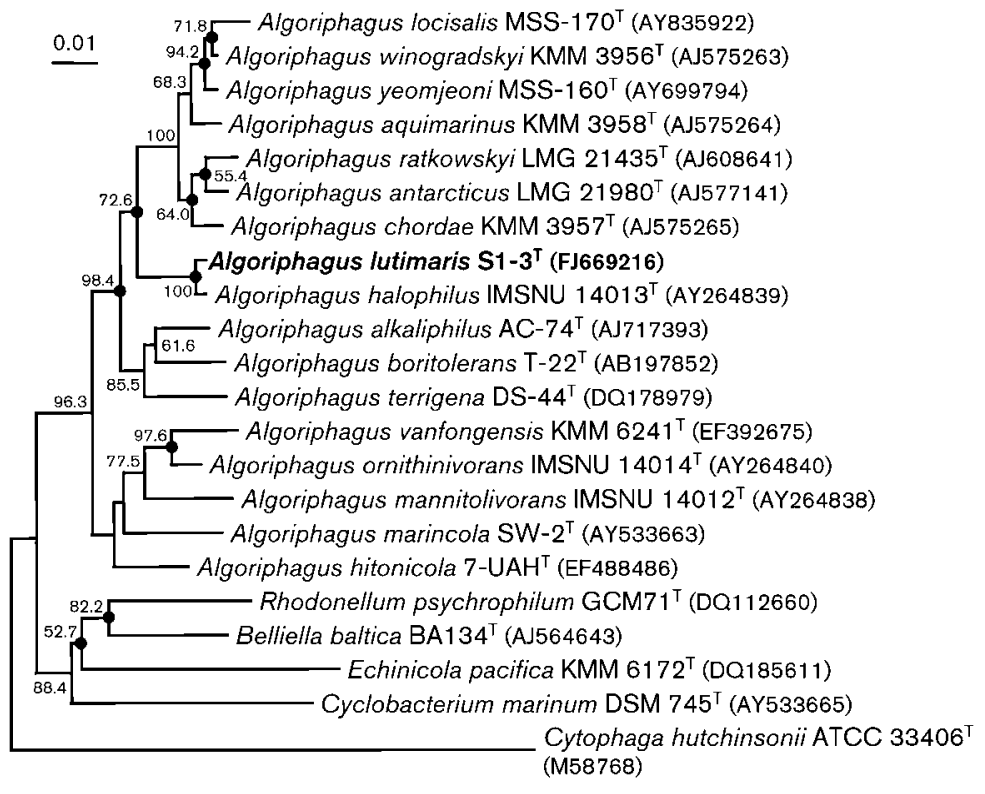

Fig. 1. Neighbour-joining phylogenetic tree based on 16S rRNA gene sequences showing the relative positions of Algoriphagus lutimaris sp. nov. $\mathrm{S} 1-3^{\top}$, other Algoriphagus species and some other related taxa. Bootstrap values (>50\%) based on 1000 replications are shown at branch nodes. Filled circles indicate that the corresponding nodes were also recovered in maximum-likelihood and maximum-parsimony trees. Cytophaga hutchinsonii ATCC $33406^{\top}$ was used as an outgroup. Bar, 0.01 substitutions per nucleotide position. 
Table 2. Cellular fatty acid compositions of strain $\mathrm{S} 1-3^{\top}$ and A. halophilus KCTC $12051^{\top}$

Strains: 1, A. lutimaris sp. nov. S1-3 ${ }^{\mathrm{T}} ; 2$, A. halophilus KCTC $12051^{\mathrm{T}}$. Data were obtained in this study and are percentages of total fatty acids; fatty acids representing $<0.5 \%$ in both strains are omitted. ECL, Equivalent chain-length; -, not detected.

\begin{tabular}{|c|c|c|}
\hline Fatty acid & 1 & 2 \\
\hline \multicolumn{3}{|l|}{ Straight-chain } \\
\hline $\mathrm{C}_{15: 0}$ & 2.2 & - \\
\hline $\mathrm{C}_{16: 0}$ & 1.1 & - \\
\hline \multicolumn{3}{|l|}{ Branched } \\
\hline anteiso- $\mathrm{C}_{11: 0}$ & 1.5 & 1.9 \\
\hline iso- $\mathrm{C}_{15: 0}$ & 21.3 & 25.1 \\
\hline anteiso- $\mathrm{C}_{15: 0}$ & 2.6 & 3.2 \\
\hline iso- $\mathrm{C}_{16: 0}$ & 4.6 & 5.0 \\
\hline iso- $\mathrm{C}_{16: 1}$ & 1.2 & 3.2 \\
\hline iso- $\mathrm{C}_{17: 1} \omega 9 c$ & 9.4 & 10.3 \\
\hline \multicolumn{3}{|l|}{ Unsaturated } \\
\hline $\mathrm{C}_{15: 1} \omega 6 c$ & 0.7 & 0.5 \\
\hline $\mathrm{C}_{16: 1} \omega 5 c$ & 3.9 & 3.5 \\
\hline $\mathrm{C}_{17: 1} \omega 6 c$ & 3.2 & 1.8 \\
\hline \multicolumn{3}{|l|}{ Hydroxy } \\
\hline $\mathrm{C}_{16: 0} 3-\mathrm{OH}$ & 1.4 & - \\
\hline iso- $\mathrm{C}_{15: 0} 3-\mathrm{OH}$ & 2.2 & 2.5 \\
\hline iso- $\mathrm{C}_{16: 0} 3-\mathrm{OH}$ & 1.4 & 2.0 \\
\hline iso- $\mathrm{C}_{17: 0} 3-\mathrm{OH}$ & 9.3 & 7.1 \\
\hline \multicolumn{3}{|l|}{ Summed features* } \\
\hline 3 & 23.5 & 19.4 \\
\hline 4 & 2.7 & 3.9 \\
\hline Unknown ECL 13.565 & - & 2.0 \\
\hline
\end{tabular}

${ }^{*}$ Summed feature represent two or three fatty acids that cannot be separated by the Microbial Identification System. Summed feature 3 consisted of $\mathrm{C}_{16: 1} \omega 7 c$ and/or iso- $\mathrm{C}_{15: 0}$ 2-OH. Summed feature 4 consisted of iso- $\mathrm{C}_{17: 1} \mathrm{I}$ and/or anteiso- $\mathrm{C}_{17: 1} \mathrm{~B}$.

as well as A. halophilus (Stackebrandt \& Goebel, 1994). Therefore, on the basis of the phenotypic, chemotaxonomic, phylogenetic and genetic data, strain $S 1-3^{\mathrm{T}}$ is considered to represent a novel species of the genus Algoriphagus, for which the name Algoriphagus lutimaris sp. nov. is proposed.

\section{Description of Algoriphagus lutimaris sp. nov.}

Algoriphagus lutimaris (lu.ti.ma'ris. L. n. lutum mud; L. gen. n. maris of the sea, marine; N.L. gen. n. lutimaris of a marine mud).

Cells are Gram-staining-negative, non-spore-forming, non-flagellated and short rods or rods $(0.4-0.7 \times 0.8-$ $4.5 \mu \mathrm{m})$; a few cells longer than $10 \mu \mathrm{m}$ are also observed. Colonies on MA are circular, convex, smooth, glistening, reddish-orange in colour and $1.0-1.5 \mathrm{~mm}$ in diameter after incubation for 3 days at $30{ }^{\circ} \mathrm{C}$. Growth occurs at 4 (weak) and $40{ }^{\circ} \mathrm{C}$ (optimum $30{ }^{\circ} \mathrm{C}$ ) but not at $45{ }^{\circ} \mathrm{C}$, at $\mathrm{pH} 5.0$ (optimum $\mathrm{pH}$ 7.0-8.0) but not at $\mathrm{pH} 4.5$ and with $0-8.0 \%$ (w/v) $\mathrm{NaCl}$ (optimum $2 \% \mathrm{NaCl}$ ). $\mathrm{Mg}^{2+}$ ions are required for growth. Growth does not occur under anaerobic conditions on MA or on MA supplemented with nitrate. Tweens 20, 40, 60 and 80 are hydrolysed. The predominant menaquinone is MK-7. The major fatty acids $(>10 \%$ of total fatty acids) are $\mathrm{C}_{16: 1} \omega 7 c$ and/or iso- $\mathrm{C}_{15: 0} 2-\mathrm{OH}$ and iso- $\mathrm{C}_{15: 0}$. Other phenotypic properties are shown in Table 1. The DNA $\mathrm{G}+\mathrm{C}$ content of the type strain is $41.4 \mathrm{~mol} \%$ (HPLC).

The type strain, $\mathrm{S} 1-3^{\mathrm{T}}\left(=\right.$ KCTC $22630^{\mathrm{T}}=$ CCUG $\left.57608^{\mathrm{T}}\right)$, was isolated from sediment of a tidal flat at Saemankum on the west coast of Korea.

\section{Acknowledgements}

This work was supported by the Program for Collection, Management and Utilization of Biological Resources (grant M10867010003) and the 21C Frontier Program of Microbial Genomics and Applications (grant MG05-0401-2-0) from the Ministry of Education, Science and Technology (MEST) of the Republic of Korea.

\section{References}

Baumann, P. \& Baumann, L. (1981). The marine Gram-negative eubacteria: genera Photobacterium, Beneckea, Alteromonas, Pseudomonas, and Alcaligenes. In The Prokaryotes, pp. 1302-1331. Edited by M. P. Starr, H. Stolp, H. G. Trüper, A. Balows \& H. G. Schlegel. Berlin: Springer.

Bowman, J. P. (2000). Description of Cellulophaga algicola sp. nov., isolated from the surfaces of Antarctic algae, and reclassification of Cytophaga uliginosa (ZoBell and Upham 1944) Reichenbach 1989 as Cellulophaga uliginosa comb. nov. Int J Syst Evol Microbiol 50, 18611868.

Bowman, J. P., Nichols, C. M. \& Gibson, J. A. E. (2003). Algoriphagus ratkowskyi gen. nov., sp. nov., Brumimicrobium glaciale gen. nov., sp. nov., Cryomorpha ignava gen. nov., sp. nov. and Crocinitomix catalasitica gen. nov., sp. nov., novel flavobacteria isolated from various polar habitats. Int J Syst Evol Microbiol 53, 1343-1355.

Bruns, A., Rohde, M. \& Berthe-Corti, L. (2001). Muricauda ruestringensis gen. nov., sp. nov., a facultatively anaerobic, appendaged bacterium from German North Sea intertidal sediment. Int J Syst Evol Microbiol 51, 1997-2006.

Chun, J., Lee, J.-H., Jung, Y., Kim, M., Kim, S., Kim, B. K. \& Lim, Y. W. (2007). EzTaxon: a web-based tool for the identification of prokaryotes based on $16 \mathrm{~S}$ ribosomal RNA gene sequences. Int J Syst Evol Microbiol 57, 2259-2261.

Cohen-Bazire, G., Sistrom, W. R. \& Stanier, R. Y. (1957). Kinetic studies of pigment synthesis by nonsulfur purple bacteria. J Cell Comp Physiol 49, 25-68.

Copa-Patiño, J. L., Arenas, M., Soliveri, J., Sánchez-Porro, C. \& Ventosa, A. (2008). Algoriphagus hitonicola sp. nov., isolated from an athalassohaline lagoon. Int J Syst Evol Microbiol 58, 424-428.

Cowan, S. T. \& Steel, K. J. (1965). Manual for the Identification of Medical Bacteria. London: Cambridge University Press.

Ezaki, T., Hashimoto, Y. \& Yabuuchi, E. (1989). Fluorometric deoxyribonucleic acid-deoxyribonucleic acid hybridization in microdilution wells as an alternative to membrane filter hybridization in which radioisotopes are used to determine genetic relatedness among bacterial strains. Int J Syst Bacteriol 39, 224-229. 
Komagata, K. \& Suzuki, K. (1987). Lipid and cell-wall analysis in bacterial systematics. Methods Microbiol 19, 161-207.

Lányí, B. (1987). Classical and rapid identification methods for medically important bacteria. Methods Microbiol 19, 1-67.

Leifson, E. (1963). Determination of carbohydrate metabolism of marine bacteria. J Bacteriol 85, 1183-1184.

Liu, Y., Li, H., Jiang, J.-T., Liu, Y.-H., Song, X.-F., Xu, C.-J. \& Liu, Z.-P. (2009). Algoriphagus aquatilis sp. nov., isolated from a freshwater lake. Int J Syst Evol Microbiol 59, 1759-1763.

Nedashkovskaya, O. I., Vancanneyt, M., Van Trappen, S., Vandemeulebroecke, K., Lysenko, A. M., Rohde, M., Falsen, E., Frolova, G. M., Mikhailov, V. V. \& Swings, J. (2004). Description of Algoriphagus aquimarinus sp. nov., Algoriphagus chordae sp. nov. and Algoriphagus winogradskyi sp. nov., from sea water and algae, transfer of Hongiella halophila Yi and Chun 2004 to the genus Algoriphagus as Algoriphagus halophilus comb. nov. and emended descriptions of the genera Algoriphagus Bowman et al. 2003 and Hongiella Yi and Chun 2004. Int J Syst Evol Microbiol 54, 1757-1764.

Nedashkovskaya, O. I., Kim, S. B., Kwon, K. K., Shin, D. S., Luo, X., Kim, S.-J. \& Mikhailov, V. V. (2007). Proposal of Algoriphagus vanfongensis sp. nov., transfer of members of the genera Hongiella Yi and Chun 2004 emend. Nedashkovskaya et al. 2004 and Chimaereicella Tiago et al. 2006 to the genus Algoriphagus, and emended description of the genus Algoriphagus Bowman et al. 2003 emend. Nedashkovskaya et al. 2004. Int J Syst Evol Microbiol 57, 1988-1994.

Reichenbach, H. (1992). The order Cytophagales. In The Prokaryotes, 2nd edn, vol. 4, pp. 3631-3675. Edited by A. Balows, H. G. Trüper, M. Dworkin, W. Harder \& K. H. Schleifer. New York: Springer.

Sasser, M. (1990). Identification of bacteria by gas chromatography of cellular fatty acids. Newark, DE: MIDI Inc.

Stackebrandt, E. \& Goebel, B. M. (1994). Taxonomic note: a place for DNA-DNA reassociation and $16 \mathrm{~S}$ rRNA sequence analysis in the present species definition in bacteriology. Int J Syst Bacteriol 44, 846-849.

Staley, J. T. (1968). Prosthecomicrobium and Ancalomicrobium: new prosthecate freshwater bacteria. J Bacteriol 95, 1921-1942.
Tamaoka, J. \& Komagata, K. (1984). Determination of DNA base composition by reversed-phase high-performance liquid chromatography. FEMS Microbiol Lett 25, 125-128.

Van Trappen, S., Vandecandelaere, I., Mergaert, J. \& Swings, J. (2004). Algoriphagus antarcticus sp. nov., a novel psychrophile from microbial mats in Antarctic lakes. Int J Syst Evol Microbiol 54, 19691973.

Wayne, L. G., Brenner, D. J., Colwell, R. R., Grimont, P. A. D., Kandler, O., Krichevsky, M. I., Moore, L. H., Moore, W. E. C., Murray, R. G. E. \& other authors (1987). International Committee on Systematic Bacteriology. Report of the ad hoc committee on reconciliation of approaches to bacterial systematics. Int $J$ Syst Bacteriol 37, 463-464.

Yi, H. \& Chun, J. (2004). Hongiella mannitolivorans gen. nov., sp. nov., Hongiella halophila sp. nov. and Hongiella ornithinivorans sp. nov., isolated from tidal flat sediment. Int J Syst Evol Microbiol 54, 157-162.

Yoon, J.-H., Kim, H., Kim, S.-B., Kim, H.-J., Kim, W. Y., Lee, S. T., Goodfellow, M. \& Park, Y.-H. (1996). Identification of Saccharomonospora strains by the use of genomic DNA fragments and rRNA gene probes. Int J Syst Bacteriol 46, 502-505.

Yoon, J.-H., Lee, S. T. \& Park, Y.-H. (1998). Inter- and intraspecific phylogenetic analysis of the genus Nocardioides and related taxa based on 16S rRNA gene sequences. Int J Syst Bacteriol 48, 187-194.

Yoon, J.-H., Kim, I.-G., Shin, D.-Y., Kang, K. H. \& Park, Y.-H. (2003). Microbulbifer salipaludis sp. nov., a moderate halophile isolated from a Korean salt marsh. Int J Syst Evol Microbiol 53, 53-57.

Yoon, J.-H., Kang, S.-J., Jung, S.-Y., Lee, C.-H. \& Oh, T.-K. (2005a). Algoriphagus yeomjeoni sp. nov., isolated from a marine solar saltern of the Yellow Sea, Korea. Int J Syst Evol Microbiol 55, 865-870.

Yoon, J.-H., Kang, S.-J. \& Oh, T.-K. (2005b). Algoriphagus locisalis sp. nov., isolated from a marine solar saltern. Int J Syst Evol Microbiol 55, $1635-1639$.

Yoon, J.-H., Lee, M.-H., Kang, S.-J. \& Oh, T.-K. (2006). Algoriphagus terrigena sp. nov., isolated from soil. Int J Syst Evol Microbiol 56, 777780. 